HJIMB Vol 1, No. 2 2019, pp: 57-60

https://doi.org/10.30606/hjimb

\title{
HIRARKI
}

Jurnal Ilmiah Manajemen dan Bisnis

http://iournal.upp.ac.id/index.php/Hirarki

\section{PENGARUH KEMAMPUAN, MOTIVASI DAN KOMPENSASI TERHADAP KINERJA PEGAWAI SEKRETARIAT DAERAH KABUPATEN ROKAN HULU}

Rina Ari Rohmah

Pendidikan Ilmu Pengetahuan Sosial, Universitas Pasir Pengaraian

\section{Info Artikel}

Sejarah Artikel:

Diterima 23 Agustus

2019

Disetujui 01 September

2019

Dipublikasikan

30 Oktober 2019

Keywords:

Kemampuan, Motivasi,

Kompensasi, kinerja

\begin{abstract}
Abstrak
Penelitian ini bertujuan untuk mengetahui bagaimana kemampuan, motivasi dan kompensasi di Kantor Sekretariat Daerah Kabupaten Rokan Hulu. Pengumpulan data dilakukan melalui penyebaran kuesioner dan dilaksanakan pada 84 pegawai Di Kantor Sekretariat Daerah Kabupaten Rokan Hulu. Analisa data pada penelitian ini menggunakan bantuan SPSS. Teknik sampling yang dipakai adalah metode sensus dan teknik pengujian data yang digunakan dalanm penelitian ini meliputi uji validitas dengan analisis faktor uji reliabilitas dengan Alpha Cronbach. Hipotesis yang menyatakan bahwa secara simultan variabel kemampuan, motivasi dan kompensasi mempunyai pengaruh yang signifikan terhadap kinerja pegawai diterima.
\end{abstract}

THE EFFECT OF ABILITY, MOTIVATION AND COMPENSATION TO THE PERFORMANCE OF EMPLOYEES REGIONAL SECRETARIAT ROKAN HULU

\author{
Abstract \\ This study aims to determine how the ability, motivation and compensation in the Regional \\ Secretariat of Rokan Hulu. Data collected through questionnaires and conducted on 84 \\ employees at the Regional Secretariat of Rokan Hulu. Analysis of the data in this study using \\ SPSS. The sampling technique used is the census methods and testing techniques used data \\ dalanm this research include test validity by factor analysis Cronbach alpha reliability test. \\ The hypothesis that simultaneous variables ability, motivation and compensation has a \\ significant influence on employee performance is accepted.




\section{PENDAHULUAN}

Sumber daya manusia memiliki peranan yang penting dalam sebuah instansi. Fokus utamanya adalah orangorang atau para pegawai. Pegawai merupakan salah satu unsur yang paling dominan dan strategis dalam usaha pencapaian tujuan sehingga dalam suatu instansi usaha memberdayakan dan mengembangkan sumber daya manusia dalam hal ini pegawai, perlu selalu ditingkatkan guna mencapai tujuan-tujuan dan hasil seperti yang dikehendaki.

Salah satu tantangan sumber daya manusia pada era globalisasi dihadapkan dengan permasalahan diantaranya yaitu faktor kemampuan kerja. Dalam hal ini kemampuan menunjukan potensi orang untuk melaksanakan tugas atau pekerjaan. Kemampuan kerja berhubungan dengan pengetahuan, bakat, minat dan pengalaman agar dapat menyelesaikan tugas-tugas yang sesuai dengan pekerjaan yang didudukinya.

Sekretariat Daerah Kabupaten Rokan Hulu merupakan salah satu Organisasi Perangkat Daerah yang mempunyai peranan penting dalam penyelenggaraan Pemerintahan di Daerah, sehingga wajib memiliki sumber daya manusia yang berkualitas serta setiap pegawainya harus mempunyai tangung jawab yang besar dalam menyelesaikan tugas yang telah diberikan oleh pimpinan, dimana Pegawai wajib memberikan pelayanan terbaik sebagai Unsur Pemerintah Daerah dan Kepada masyarakat. Selain itu Sekretariat Daerah merupakan salah satu organisasi Perangkat Daerah yang memiliki peran dalam meningkatkan kinerja yang selama ini dianggap kurang maksimal.

Kemampuan kerja pegawai merupakan keahlian yang dimiliki pegawai dalam mengerjakan pekerjaanya. Apabila pegawai mendapatkan kesempatan untuk mengembangkan bakat yang dimiliki, serta menggunakannya secara tepat akan berpengaruh pada kemajuan instansi. Selain itu dengan kemampuan yang memadai akan membantu pegawai dalam melaksanakan pekerjaan sekarang dan pekerjaan yang akan datang. Salah satu yang menganggu kinerja birokrasi pemerintah adalah penempatan pegawai dalam jabatan yang tidak didasarkan pada kemampuan persyaratan jabatan struktural. Dilingkungan PNS, pangkat tidak selalu mencerminkan kemampuan atau prestasi, kerana pangkat ditetapkan berdasarkan ijazah tertinggi yang dimiliki pegawai serta masa kerja dipemerintahan, dengan tidak membedakan jenis keahlian yang mereka

Bahwasannya kemampuan pegawai dilihat dari tingkat pendidikannya lebih dominan pada jenjang pendidikan SLTA atau sederajat dan pada jenjang pendidikan Sarjana (S1), sedangkan pada jenjang pendidikan strata 2 atau S2 hanya dimiliki oleh pegawai sebanyak 5 orang. Hal ini berdampak pada penguasaan berbagai kemampuan lainnya yang harus dimiliki dan dikuasai, meskipun pada kenyataannya tingkat pendidikan formal (melalui jenjang pendidikan) bukanlah merupakan faktor penentu bagi seorang pegawai untuk mengukur tingkat kemampuan yang dimilikinya. Namun harus juga didukung oleh kemampuannya menguasai materi atau tugas yang menjadi tanggungjawabnya yang ditunjang oleh penguasaan sarana dan prasarana dan alat teknologi lainnya. Selain menurut jenjang pendidikan kenaikan pangkat pun diberikan kepada pegawai yang berprestasi baik, sehingga prestasi pegawai yang mendapatkan kenaikan pangkat tentunya pegawai mempunyai kemampuan dan prestasi yang baik.

Pemberian motivasi bertujuan untuk mendorong semangat kerja para pegawai 
agar mau bekerja secara optimal dengan memberikan semua kemampuan dan keterampilan untuk memperoleh hasil yang maksimal. Pemimpin yang mengarahkan pegawainya melalui motivasi akan menciptakan kondisi dimana pegawai merasa mendapatkan inspirasi untuk bekerja keras, pegawai yang mempunyai motivasi tinggi sangat penting kinerja yang dihasilkan tinggi ingin dicapai secara konsisten. Dengan adanya motivasi yang tinggi seorang pegawai akan mampu meningkatkan kinerjanya dan dinilai oleh pimpinan akan bagus.

Untuk dapat mengikuti segala perkembangan yang ada dan tercapainya tujuan suatu instansi maka perlu adanya suatu motivasi agar pegawai mampu bekerja dengan baik, dan salah satu motivasi itu adalah dengan memenuhi keinginan-keinginan pegawai antara lain: gaji atau upah yang baik, pekerjaan yang aman, suasana kerja yang kondusif, penghargaan terhadap pekerjaan yang dilakukan, pimpinan yang adil dan bijaksana, pengarahan dan perintah yang wajar, organisasi atau tempat kerja yang dihargai masyarakat atau dengan mengupayakan kompensasi yang besarannya proporsional dan juga bersifat progresif yang artinya sesuai dengan jenjang karir, karena kompensasi sangat diperlukan untuk memacu kinerja para pegawai agar selalu berada pada tingkat tertinggi (optimal) sesuai kemampuan masing-masing.

Dari tabel diatas terlihat bahwa pemberian kompensasi di Kantor Sekretariat Daerah Kabupaten Rokan Hulu belum proporsional yaitu masih terlihat bahwa pemberian kompensasi belum berdasarkan jenjang karir (sub golongan) yaitu kabag keuangan (IV/a), staf (IV/a) dan kabag persidangan (IV/d) masih belum proporsional. Pemberian kompensasi merupakan salah satu hal pokok yang harus diperhatikan oleh organisasi. Semangat tidaknya karyawan bisa juga disebabkan oleh besar kecilnya kompensasi yang diterima. Apabila karyawan tidak mendapatkan kompensasi yang sesuai dengan besarnya pengorbanan dalam bekerja, maka karyawan tersebut cenderung malas bekerja dan tidak bersemangat yang ada akhirnya mereka bekerja semaunya tanpa ada motivasi yang tinggi.

\section{METODE PENELITIAN}

Penelitian ini dilaksanakan di Kantor Sekretariat Daerah Kabupaten Rokan Hulu. Untuk penelitian ini populasi yang digunakan ialah seluruh pegawai di kantor Sekretariat Daerah Kabupaten Rokan Hulu yang berjumlah 84 orang, karena jumlah populasi lebih kecil 100 maka penulis dalam penelitian ini menetapkan seluruh populasi menjadi sampel atau disebut juga dengan sensus, Jadi jumlah sampel dalam penelitian ini adalah 84 orang. Analisa data pada penelitian ini menggunakan bantuan SPSS. Teknik analisa data penelitian ini adalah analisa deskriptif menggunakan TCR (Tingkat Capaian Responden), uji normalitas, uji heterokedastisitas, uji multikolonieritas, uji $\mathrm{F}$, uji $\mathrm{t}$, koefisien determinasi $\left(\mathrm{R}^{2}\right)$ dan analisa regresi linier berganda yaitu

$$
Y=a+b_{1} x_{1}+b_{2} x_{2}+b_{3} x_{3}+b_{4} x_{4}+e
$$

\section{HASIL DAN PEMBAHASAN}

Berdasarkan nilai masing-masing variabel dari perhitungan TCR dari indikator kemampuan dengan nilai TCR 74.6\% pada kriteria cukup baik, hal ini perlu dilakukan langkah-langkah perbaikan oleh Kantor Sekretariat Daerah Kabupaten Rokan Hulu seperti 
Untuk perhitungan TCR dari motivasi diperoleh nilai sebesar $80.4 \%$ dengan kriteria baik, hal ini pegawai termotivasi untuk bekerja karena adanya gaji yang sesuai, kenyamanan dalam bekerja dan kejelasan status dalam kantor

Untuk perhitungan TCR dari kompensasi diperoleh sebesar $80.6 \%$ dengan kriteria baik, hal ini berarti pemberian kompensasi mempunyai pengaruh yang baik terhadap kinerja pegawai, seluruh pegawai telah menerima kompensasi maka kinerja pegawai akan berjalan dengan efektif dan efisien

Perhitungan TCR untuk variabel kinerja sebesar $81.2 \%$ dengan kriteria baik, hal ini bahwa pegawai dapat menyelesaikan suatu pekerjaan dengan ketelitian yang tinggi dan selalu mengikuti prosedur kantor sehingga kualitas hasil kerja tetap terjaga. Pengaruh kemampuan, motivasi dan kompensasi terhadap kinerja pegawai

Hasil pengujian diperoleh nilai $\mathrm{t}$ hitung untuk variabel kemampuan menunjukan nilai $\mathrm{t}$ hitung $=0.206$ dengan nilai signifikan $0.003<0.05$, yang berarti bahwa hipotesis variabel kemampuan memiliki pengaruh yang signifikan terhadap kinerja pegawai Kantor Sekretariat Kabupaten Rokan Hulu. Hasil pengujian diperoleh nilai $t$ hitung untuk variabel motivasi menunjukan nilai t hitung $=2.257$ dengan signifikan $0.002<0.05$, yang berarti bahwa hipotesis variabel motivasi memiliki pengaruh yang signifikan terhadap kinerja pegawai Kantor Sekretariat Kabupaten Rokan Hulu. Sedangkan Hasil pengujian diperoleh nilai $t$ hitung untuk variabel kompensasi menunjukan nilai $\mathrm{t}$ hitung $=$ 6.779 dengan signifikan $0.000<0.05$, yang berarti bahwa hipotesis variabel kompensasi memiliki pengaruh yang signifikan terhadap kinerja pegawai Kantor Sekretariat Kabupaten Rokan Hulu

\section{KESIMPULAN}

Dari pembahasan yang telah diuraikan, maka dapat ditarik kesimpulan sebagai berikut, Berdasarkan nilai masing-masing variabel dari perhitungan TCR dari indikator kemampuan dengan nilai TCR $74.6 \%$ pada kriteria cukup baik, perhitungan TCR dari motivasi diperoleh nilai sebesar $80.4 \%$ dengan kriteria baik, perhitungan TCR dari kompensasi dengan nilai $80.6 \%$ dengan kriteria baik, dan untuk perhitungan TCR dari kinerja dengan nilai $81.2 \%$ pada kriteria baik. Kompensasi memiliki pengaruh yang signifikan terhadap kinerja pegawai Kantor Sekretariat Kabupaten Rokan Hulu. Kemampuan, motivasi dan kompensasi mempunyai pengaruh yang signifikan terhadap kinerja pegawai diterima.

\section{DAFTAR PUSTAKA}

Ambar Teguh Sulistiyani dan Rosidah. 2010. Manajemen Sumber Daya Manusia, Graha Ilmu Yogyakarta

Arikunto, Suharsimi. 2010. Prosedur Penelitian. Suatu Pendekatan Praktek.Jakarta: Rineka Cipta

Ati Cahyani. 2010. Pengaruh Motivasi dan lingkungan kerja terhadap kinerja karyawan pada CV. Citra Luhur-Bali, Skripsi. Universitas Brawijaya, Malang

Binardi. 2013. Pengantar Bisnis. Penerbit : Pabelan. Bandung.

Decy dan Ryan. 2010. Organisasi dan Motivasi. Bumi Aksara. Bandung

Handoko. 2011. Manajemen Edisi 2, BPFE, Yogyakarta 
Hasibuan S.P Melayu, 2010. Manajemen Sumber Daya Manusia, Rineka Cipta, Jakarta.

Harsono. 2010. Pengaruh Gaya Kepemimpinan , Motivasi dan Kemampuan Kerja terhadap Kinerja Pegawai Sekretariat Daerah Kabupaten Rembang. UNDIP Semarang.

Husein Umar. 2013. Kompensasi. Jakarta :Rajawali Pers

Malthis. 2010. Human Resource Management. International Student Edition. South-Western, Adivision Of Thomson Learning, In Singapore

Mangkunegara. 2011. Evaluasi Kinerja SDM. Bandung. Refika Aditama.

Manulung. 2010. Manajemen Tenaga Kerja , Karyadarma IIP. Jakarta

Nawawi. 2011. Organisasi Sekolah dan Pengelolaan Kelas. Jakarta: Gunung Agung.

Rivai Jauvani. 2012. Manajemen Sumber Daya Manusia untuk Perusahaan, Edisi ke dua, Raja Wali Pers, Jakarta.

Robbins dan Merry. 2012. Organisational Behavior. New Jersey:Pearson International Edition.

Schumacher. 2010. Research in education. New jersey : Pearson

Sedarmayanti, 2014. Manajemen Sumber Daya Manusia Reformasi Birokrasi dan Manajemen Pegawai Negeri Sipil. Bandung. Refika Aditama.
Sondang P. Siagian. 2010. Kiat Meningkatkan Produktivitas Kerja. Jakarta. Rineka Cipta.

Sugiyono. 2013. Metode Penelitian Kombinasi (Mixed Methods), Penerbit ALFABETA, Bandung

Wursanto. 2013. Dasar-dasar Perilaku Organisasi. Yogyakarta : Andi 